\title{
Turgut Cansever'in Şehirciliği Üstüne Dilbilimsel Değiniler
}

\author{
* \\ Fatma Sinem Akbulut 1
ORCID: 0000-0002-6621-0436
}

Öz

Turgut Cansever, İslam düşüncesini mekânın üretiminde temsil etmek üzere inançsal ilkelerle yapılı çevre arasında şu bağıntıyı kurmuştur: Yeryüzü, tevhit inancı etrafinda biçimlenen ilahi bir yansimaysa dahi yeni öznellikler üretecek özerk varlıkların insan eliyle organize edilmekte olduğu bütünsel bir uzamdır. Bu düşünce, tasarım kuramı olduğu kadar toplumsal karşılıklara da sahiptir. Ayrıca, Cansever, önerileriyle tutarl yapılar tasarlayıp inşai faaliyetlerde bulunmuştur. Bu çabalarında, geleneksel yapı inşa etme bilgisinin muhafaza edilmesi hâlinde mimaride, şehircilikte ve toplumsal alanda yaratıcılığın nasıl mümkün olabileceğini göstermek istemiştir. Bu yazı, ilkin söz konusu önerileri Saussure'ün Dil ve söz ikiliğine yaslanarak kavramaya çalışmış; ardından dilbilimde öne çıkan metafor ve metonimi kavramlarıyla değerlendirmeyi vadetmiştir. Çalışmada öncelikle Saussureyen yapısalcı geleneğe ait bu kavramların kültürel çalışmalarda analizlere altlık olduğuna işaret edilmiştir. Bununla, metaforun ideal bir anlama ayrıcalık tanımak için elle tutulur bir imgeyi öne sürmeye yaradığına, böylece iktidarı dokunulmazlık zırhına büründüren bir temsil tarzı olduğuna kanaat getirilmiştir. Aksine metonimik bağlantılarınsa otoriter anlam yüklerini boşaltıp toplumsal sıradüzenin altını kazımaya davet ettiği savlanır. Bu argümanları takip ederek, neticede, nesne ya da olguları bağlamlarına gönderimde bulunmaya sevk ettiğinden Cansever'in tercihini bu ikinci temsil tarzından yana kullandığı sonucuna varılmıştır. Dolayısıyla çalışma, semiyotikten Dil ve sözle metafor ve metonimi kavramlarını ödünç alıp onun satır aralarındaki fikirlerini anlayabilmekle ilgilenmiştir.

Anahtar Kelimeler: dil, söz, metafor, metonimi, Turgut Cansever

\footnotetext{
${ }^{1}$ Arş. Gör., Gazi Üniversitesi, E-mail: sinemulusoy@gazi.edu.tr

idealkent (c) Kent Araştırmaları Dergisi (Journal of Urban Studies)

http://idealkentdergisi.com

Geliş Tarihi Received Date: 15.09.2020 Kabul Tarihi Accepted Date: 21.12.2020
} 


\title{
Linguistic Considerations on Turgut Cansever's Urbanism
}

\author{
Fatma Sinem Akbulut ${ }^{2}$ \\ ORCID: 0000-0002-6621-0436
}

\begin{abstract}
Turgut Cansever has established the following relation between the religious principles and the structured environment in order to represent the Islamic thought in the production of space: Even if the earth is a divine reflection shaped around the belief of "tawhid", it is a holistic space in which autonomous beings producing new subjectivities are organized by human hands. This article first tried to grasp these mentioned proposals on the basis of Saussure's duality of langue and parole; it, then tried to evaluate them with the concepts of metaphor and metonymy that are significant in linguistics. First of all, it has been witnessed that these concepts belonging to the structuralist tradition of Saussurean are base for analysis in cultural studies. At this point, it has been concluded that metaphor serves to put forward a tangible image in order to privilege an ideal meaning, thus it becomes a mode of representation that makes power inviolable. On the contrary, it has been said that metonymic connections invite to undermine the social hierarchy by emptying authoritarian meaning. Thus, borrowing the concepts of metaphor, metonym, langue and parole from semiotic this article interest in understanding his ideas between the lines.
\end{abstract}

Keywords: langue, parole, metaphor, metonymy, Turgut Cansever

${ }^{2}$ R. A., Gazi University, E-mail: sinemulusoy@gazi.edu.tr.

idealkent (c) Kent Araştırmaları Dergisi (Journal of Urban Studies)

http://idealkentdergisi.com

Geliş Tarihi Received Date: 15.09.2020 Kabul Tarihi Accepted Date: 21.12.2020 


\section{Kültürel Temsilin Dikotomik Enstrümanları ${ }^{3}$}

Ferdinand de Saussure, Dil (langue) ile söz (parole) arasında bir ayrım getirir. Öncelikle, dil sistemi, toplumsal bir kurum olmakla birlikte değerler dizgesidir de. Bu iki durum birbiriyle ilintili; zira toplumsal bir ürün olarak Dil, bir topluluğa mensup olanlarca kabul edilecek yasaları taşıyan bir sözleşmedir. Başka deyişle Dilin kullanıcısı olmak, üzerinde uzlaşılan toplumsal kuralları öğrenmeyi gerekli kılar. Buna karşın söz ise, dil sisteminin imkân sunduğu ölçüde bireysel bir seçme ve gerçekleştirme edimidir. O hâlde söz, Dilin tek sefere mahsus olarak bireysel bir tasarrufa indirgenmesidir (Barthes, 1993, s.25-27). Söz olmaksızın dilin bir sistemi mevcuda getirmesi olanaklı değildir; gerçi dil sistemi de iyi iletişim kurabilmek lehine söz edimlerine mukavemet gösterip hâlihazırdaki kurallarını bireysel kullanımlara dayatır. Öyleyse Dil, bildirişim kurmak için gerekli toplumsal bir kurumken sözse şahıslara özgüdür. Dolayısıyla Dil, birey ötesi bir soyutlamayken söz, bireylerin somut kullanımlarıdır. O hâlde Dil, toplumsal belleğe; sözse kişisel yaratıma ilişkindir (Rifat, 1998, s. 24). Fakat Saussure'e göre kullanıcı olmak, sözün söyleniş biçimi olan gösterenle çağrıştırdığı kavram, yani gösterilen arasındaki nedensiz ilişkiyi bilmeyi de gerektirir.

Saussure, göstergelerin, örneğin sözcüklerin, aralarında irtibatlar kurmasıyla bir sistemin nasıl mümkün hâle gelebildiğini soruşturduğunda kendilerine has değerler üreten iki eksenden de söz eder: bu iki eksenden ilkine, dizimler (syntagma) düzlemi adını verir. Saussure'ün dizimden kastı, dilsel ögelerin ya da göstergelerin uzamdan temel alıp art arda sıralanmasıdır. Başka deyişle dizim, göstergelerin birbirine eklemlenip zincirler kurmasına olanak veren bir dilsel ilkedir. Hiç şüphesiz, bu birleştirme işlemi esnasında farklı dilsel ögelerin eşzamanlı olarak telaffuzu söz konusu değildir; dolayısıyla bu terkip, art zamanlı bir işlemdir. Bu durumda dilsel ögeler, değerini ondan önce ve sonra gelecek diğer ögelerle kurduğu bağ içinde gerçekleşmiş (actuel) olarak edinir. Saussure, böylelikle, söz zinciri içerisinde aynı yerde kâin (in praesentia) ögelerin birbirine bağlı olduğunu göstermek ister. O hâlde Saussure için dizimler düzleminin bir söylem inşa etmek demek olduğu sonucuna varllabilir (Barthes, 1993, s. 50).

Bununla birlikte Saussure'ün ikinci ekseni, çağrışımlar düzlemidir. Bu eksen üzerindeyse dilsel ögeler; ses, anlam ya da farklı bir benzerlik yönünden başka dilsel ögeleri çağrıştırarak dizileri (paradigma) meydana getirir. Diziler,

\footnotetext{
${ }^{3}$ Bu makale, Fatma Sinem Akbulut'un Gazi Üniversitesi Fen Bilimleri Enstitüsü Mimarlık Anabilim Dalı'nda Neşe Gurallar danışmanlığında yürütülen doktora tez çalışmasına dayanarak üretilmiştir.
} 
dizimlerden farklı olarak birlikte mevcut olamayan birimlerden oluşmuştur; sahi, çağrışım ekseninde bir dilsel ögenin bir ötekine bağlanışı ancak birbirlerinin yokluğunda (in absentia) gerçekleşebilir. İnsan zihnindeki bellek havuzu içerisinden, benzerlik ilişkileri olan ögeler arasından birbirinin yerine geçebilen bir teki tercih edildiğinde işte o öge, çağrışım yoluyla diğer ögeleri de gücül (virtual) olarak içerisinde barındırır (Barthes, 1993, s. 50).

Dizimsel ile çağrışımsal bağlantıları izah ederken mimarlıktan örnek veren Saussure (1998), “[b]u iki açıdan, dil birimi bir yapının belli bir bölümüyle, örneğin bir sütunla karşılaştırılabilir", der. Ona göre bir sütun, ilk bağlantısını taşımakta olduğu baştabanla kurar; "[u]zamda bir arada bulunan bu iki birimin sunduğu düzen dizimsel bağıntıyı düşündürür". İkinci bağlantı ise sütunun olası biçemleriyle ilgilidir. Örneğin bir sütun, "Dor biçemindeyse, uzamla onunla birlikte yer almayan öbür biçemlerle (İyon, Korint, vb.) de anlıksal bir karşılaştırmaya yol açar: Bu bağıntı çağrışımsaldır" (s. 182). Özetle, sütunla baştabanın birinin ardından diğerinin yan yana gelmesi bir dizim oluşturmak iken sütunun Dor değil de eş zamanda, onun yerine ikame olabilecek İyon veya Korint biçeminde dahi olabilme ihtimalleri çağrışımsaldır. Sonuçta bir mimari yapının, yani dizgenin birimi olan sütun parçası, diğer birimlerle dizimsel, başka ifadeyle bitişik ilişki kurarken yine aynı sütun, çağrışım yoluyla diğer muhtemel sütunlarla benzeşiktir.

Roman Jakobson ise toplumsal bir kurum olan Dil ile bireysel bir dil etkinliği olan söz ayrımının dizimler ve çağrışım düzlemlerine denk düştügü̈nü ileri sürmüştür. Başka deyişle Jakobson, Saussure'ü takip ederek onun iki farklı modellemesinin mütekabil olduğunu düşünür (Barthes, 1993, s. 51). Ona göre çağrışımsal düzlem, kültürel bellek içinden edimselleşme (actually) ihtimali taşıyan ögeler arasından bir seçime dayanıyorsa Dil ile ilişkilidir. Bunun gibi, dizimler düzlemiyse gerçekleşmiş bir etkinlik olarak yan yana getirmeye dayandığı için söze karşılık gelir. Başka bir ifadeyle, seçme ekseni, toplumsal kuralları taşıyan Dile, birleştirme ekseniyse bu kurallara rıza göstererek dilsel sistem içerisinde edimlerde bulunacak bireysel kullanıcıların ortaya koyduğu söze ilişkindir (Tura, 1996, s. 104-05). Bu nedenle Jakobson için bir konuşma, "belli dilbilimsel kendilikler arasında bir seçmeyi ve bunların daha üst derecede bir karmaşa içinde birleşimini içerir" (alıntılayan Lodge, 2003, s. 65). Neticede artık Jakobson, Saussure'ün seçme işlemine dayalı bağlantılarını eğretileme, diğer ismiyle metafor; buna karşın dizimsel ya da birleştirme bağlantılarını ise düzdeğişmece, yani metonimi kavramları et- 
rafında ele alacak (Barthes, 1993, s.51) ve böylelikle, Dilde benzerlikler yoluyla kurulan metaforik ve bağdaştırmayı öne çıkaran metonimik söylemleri keşfetmiş olacaktır (Jakobson, 2003, s.76).

Roland Barthes'a (1993) göre seçme eksenine bağlı bir dizge, bir bedenin "aynı noktasında, aynı anda bulunamayacak olan ve değişimi giyimsel bir anlam değişmesine yol açan parçalar, ek parçalar ya da ayrıntılar öbeği" gibidir. Söz gelimi takke, bere ve şapka birbirinin yerini metaforik olarak tutar. Öte yandan, "aynı kıyafette değişik ögelerin yan yana bulunması" ise birleştirme işlemidir; etek, bluz ve ceket kombine edildiğinde metonimik bir dizim oluşturur (s. 53). Örneğin bir kadın, önce bedenin belirli yerlerine giyilebilecekler arasından, yani pantolon yerine etek ya da gömlek yerine bluz, bir seçim yapar ve ardından bu giysileri yan yana getirerek bir kombinasyon oluştur (Lodge, 2003, s. 65-66). Bazı giysiler estetik ya da toplumsal bakımdan mutabık bir dizge oluştururken bazı dizgelerdeyse uyumsuzluk göze çarpabilir. Bunun yargısı şüphesiz Dilin toplumsal bir sistem olmasıyla ilgilidir. Kısaca, bir kadın; etek, bluz ve ceketten mürekkep bir kombinasyon oluşturduğunda, bir söylem inşa etmiş olur. Başka deyişle konvansiyonel olarak bir araya gelen ögeler, bir bağlam oluşturarak söylemi kuran birey hakkında fikir verir; dolayısıyla bir kombinasyonun giyilmesi aslında semiyotik bakımdan sunulan bir bildirimdir.

Ancak dikkat edilmeli ki, Jakobson'un kavradığı hâliyle, bu örnekteki gardıroptan, yani tıpkı kültürel bellekten seçilip birbirine alternatif oluşturacak ögeler tıpkı Dile ve tek kullanımda bir araya getirilecek parçalarsa Söze karşllık gelir. Bu noktada Saussure gibi Roland Barthes (1993) da bir örneğini mimarlıktan verir: "Bir yapıdaki ögelerden birinin üslup bakımından gösterdiği çeşitlilik, değişik dam, balkon, giriş, vb. biçimleri" metaforik dizgeler, "yapının bütünü içinde ayrıntıların birbirine bağlanışı" ise pekâlâ metonimik dizimlerdir (s. 53).

Jakobson, metafor ile metonimi arasındaki bir uyumsuzluktan da söz eder; bu iki retorik araç arasında, birinin diğerine göre öne çıkabileceği bir bağdaşmazlık bahse konu olabilir. Ona göre (2003), dilin iki kutuplu yapısı olan metafor ve metonimi, olağan sözel davranışta uyum içinde işlemektedir örneğin konuşma bozukluğu olan söz yitimi (aphasia) hâlindeyse bir eksen diğerine baskın çıkabilir (s. 76). Ancak burada bizi esas ilgilendiren, bu hâlin kültürel ögeler ya da sanat akımları söz konusu olduğunda da aynı şekilde kabul edilmesidir. Jakobson, sözü sanat tarihlerinden örneklere getirdiğinde, 
nesnenin bir dizi kapsamlayıma [synechdoch] dönüştüğü kübizmin işte metonimik bir yönelime sahip olduğunu, buna karşlık sürrealist ressamlarınsa onlara metaforik bir tutumla cevap verdiklerini düşünmüştür (s. 77).

Jakobson'un metafor ve metonimi ihtilafının bireysel ya da toplumsal temsil süreçlerinde bile kendini gösterdiğini savunmasıyla bu retorik araçlarla kültürel temsillerin çözümlenmesine kapı aralanır. Hangi kültürel bağlamların içerisinde bulunulduğuna dair algılara, kültürel bağlamların kullanıcılar tarafından gönüllülük esasıyla nasıl içselleştirilip yeniden üretileceğine yön veren yapılı çevre de bu hâliyle toplumsal gerçekliği kuran kültürel temsiller sistemini taşır. Ancak, metafor ve metonimi kavramları üzerinden bir şehircilik okumasına geçmeden önce, bu ikilinin dilbilimsel retorik araçlar olmaktan çıkarılıp Jakobson'un araladığı kapıdan geçerek kültürel temsilleri çözümleyebilen kavramlar olarak işe koşulması gerekir. Doğrusu, Ryan ve Kellner, sinema üzerine çalışmalarında tam olarak bunu gerçekleştirmiş; yeniden yorumladıkları bu kullanışlı kavramlardan, kültürel temsillerin ilki dikey ve idealize edici, ikincisi yatay ve maddesel kılan iki eksenini ifade etmek için yararlanmışlardır. Yazarların getirdiği bu yeni yaklaşım, toplumsal retoriğin bu kavram çiftini, bu nokta eleştiriye açı olmakla birlikte, radikal bir şekilde zit kutuplar olarak, gerilim temelinde tanımlamak olmuştur.

Ryan ve Kellner'e (2010) göre birincisi, metaforlar, “bir imgenin üzerine ideal ya da yüksek bir anlam yüklerler". Mesela bir kartal imgesi, özgürlük idealinin yerini tutabilir (s. 39). Bu durumda ideoloji, bir kartal imgesine metafor yoluyla özgürlük ideali gibi yüksek bir anlamı kazandırırken buna koşut olarak, özgürlük ideali bu metaforun vasıtasıyla ideolojik bakımdan toplumsal gerçeklik algısını dönüştürür. Öte yandan, kültürel temsillerin kullanımındaki bir başka uygulayımsa metonimidir ki bu, "bitişik konumdaki ya da bir bütünle ilişkisi olan ayrı ayrı nesneler arasındaki bağlantının mecazi ifadesidir". Mesela bir metafor olarak özgürlük idealine işaret eden kartal imgesi, metonimik temsilde bu kez sözcüğün gerçek anlamını imleyen söz gelimi kuş yuvası, orman, soyu tükenmekte olan türler, avcılar gibi bir dizi farklı anlamın yanına yerleşerek "elle tutulur gerçekliğin belirli bir parçasına işaret eden bir gösterge" (s. 40) olup karşımıza çıkar.

Dolayısıyla ideoloji, bağlamından koparılmış bir kartal imgesinin her ne kadar özgürlük idealine tek başına işaret etmesini istese de özgürlük idealinin aşmaya çalıştığı; avcılar, soyu tükenen türler gibi kartal imgesinin somut bağlantıları, yani metonimik ilişkileri, bu anlamsal dayatmanın karşısında duracaktır. Başka deyişle, anlamın inşasında bağlam, üzerine geçirilmeye çalışılan anıtlaştırışı ideolojik kodlara karşı direnecektir. Bu noktada Ryan ve 
Kellner (2010), metafora yaslanan söylemlerdense temsilin metonimik tarzını işte şu nedenle tercih etmiştir: Metonimi, "dünyaya, maddesel bağlantıları göz ardı eden idealize edilmiş bir kavrayışla bakmak yerine, gerçek toplumsal sistemin farklı boyutları arasındaki bitişik, maddesel ve bağlamsal bağıntıları ön plana çıkarır; 'özgürlük' gibi ideolojik anlamlarda yatan savları kendi maddesel gerçekliğine oturtarak çözümlemesi bakımından, ideoloji karşıtı bir temsil biçimidir" (s. 40).

Burada Ryan ve Kellner' in metafor ve metonimiyi yeniden ele almaları dikkate değerdir. Önce de değindiğimiz gibi metafor Dilin dikey, paradigmatik, başka deyişle seçmeye dayanan ilişkiler ekseninde gıyabında olanla ilişkiliyken metonimi yatay, sentagmatik, başka deyişle birleştirmeye, kombine etmeye dayanan ekseninde, mevcut olana dairdir. Yine değindiğimiz üzere, metafor, dil sisteminin eş zamanlı bir çalışma ilkesiyken metonimi dilin art zamanlı işleyişini anlatır. Bu konuyu, dilin işleyişinden kültürel temsillere taşıyalım. Ryan ve Kellner'ın örneğindeki kartal imgesi ile bu metaforun üstlendiği örtülü, mevcut olmayan anlamı, kısaca özgürlük ideali eş zamanlı olarak belirlenmiştir. Buna karşın kartal imgesi, mevcutta olan, etrafını bürüyen bağlantıları içerisinde metonimik bir temsil tarzına art zamanlı olarak kavuşmuştur. Ancak kartal imgesiyle özgürlük ideali arasında kurulacak bir metaforik ilişki, anlamsal bir uzlaşıya dayanmak zorundadır. Özgürlük idealini imleyen kartal imgesinin bu anlamın taşınmasına aracıllk ettiği bahsinde bir mutabakatın yokluğunda bu metaforun da bir hükmü kalmayacaktır. Bu nedenle metaforik ilişkileri inşa eden kurumlar, ideolojiler, üstelik hâkim ideolojiler, ortaya atılan imge ile mevcutta onun karşılığı olmayan anlamın arasında zorunlu bir bağ olduğunun bilinmesini ya da buna inanılmasını empoze etmeye başlayacaktır.

Ryan ve Kellner'a (2010) göre metafor, esasında otoriteyle ilişkilidir. Çünkü metaforlar, farklı düşünme formlarını çoğaltmak yerine kimlikleri öne çıkarır; benzetimsel düşünme biçimlerine ayrıcalık tanır. Metaforlar, imgelerin verili bir anlam yüküyle donatılmasına, onunla özdeş kabul edilmesine aracılık eder. Bu gerekçeyle metafor, imgelerin içerisinde bulundukları maddi bağları, özgül koşulları, dolayısıyla belirmelerindeki değişken şartları, bir başka ifadeyle bağlamlarını dışarıda tutarak onların evrenselci bir perspektif içerisinde okunmalarına neden olur. Nedeni şu ki, bir imge ile ideal arasında benzetimsel bir anlam üzerinden metaforik ilişki kurulması, bu verili, stabil ve münferit anlamın daima ve her yerde geçerli olduğunu da imleyecektir. Bu sebeple Ryan ve Kellner için metafor, "paradigmatiktir (düzen belirtir), hipotetiktir (imgeyi anlamın arkasına itmeyi belirtir) ve ayırıcıdır 
(ya/ya da önermeleri biçiminde çalışır)". O halde bu yazarlara göre metaforlar, "ideal anlamları maddesel imgelerin üzerine yerleştirmesi ve ilkini imtiyazlandırması nedeniyle dikey ve hiyerarşiktir" (s. 41).

Metonimiye sıra geldiğindeyse manzara aksi gibidir; bu "hem/hem de" önermeleri biçiminde işlerlik kazanır. Metonimi, dilbilimsel ifadeyle parataktiktir; anlam yükünü bir ideale nakletmek yerine bir bağlam etrafında yan yana getirilmiş ögelere dağıtır. Ryan ve Kellner (2010), bu bitiştiricilik (conjunctive) tarzının bir düşünceyi yatay ve eşit yönlendirmeye yaradığını belirtip şöyle devam eder: "[B]ağlantıların akışını kesecek ideal anlamlar barındırmadığı için, anlamın metonimik retoriksel tarzda yanal yayılımı potansiyel olarak sınırsızdır. Metaforun gelenekselci yönelimine karşıt olarak metonimi gelecek yönelimlidir, dinamik ve belirlenimsizdir. Bitişik ilişki ya da bağlantılar çok sayıda ve kestirilemezdir, bir üstünlük kurma (ideal anlamın imgeye üstünlüğü) ya da semantik eşdeğerlik düzeni içinde sınırlanamazlar. Metonimi eşyayı benzetimsel olarak tanımlamaktansa, aralarındaki bağlantılılığı tanıyarak farklılıklarını olumlar. Metonimi evrenselci ya da kimlikçi değil, ampirik, farklılaşmış ve tikeldir; anlamı sabit kalıplar içinde belirleyen semantik eşitleme paradigmalarını yapı çözüme uğratır ve yıkar" (s. 41).

Bu yazarlara (2010) göre metaforik ilişkilendirme tarzlarının metonimiye üstünlügü̈, ideolojiler tarafından güvence altına alınmıştır. Bu, şundan dolayıdır: Metaforlar sayesinde ideolojilerin işaret edip yönlendirdiği ideal anlam, somut imgeleri perdelemekte; böylelikle kodlar, bağlamın üstüne kapanmaktadır. Metaforlar aracılığıyla kurulan mutlak anlamın bağlam karşısındaki bu hiyerarşisi; kurulu düzeni sıkıya alan, kendini buradan temellendiren iktidarın elini güçlendiren bir temsil tarzı olarak karşımıza çıkar. Aksine, metonimik bağlantılarsa metaforların kimlik temelli, kutsallık atfedilmiş bu anlam bagajını boşaltmaya çalışıp ideolojiler tarafından ayakta tutulan toplumsal hiyerarşinin içini oymaya, bütünü oluşturan parçaların bir araya getirilişinde parçalar arasındaki eşitliğe ve başka potansiyel anlamları dahi çoğaltmaya davet edecektir (s. 40-41). Kısaca, ideolojilerin toplumsal gerçekliğin inşası için kullandıkları temsil stratejisi, belirlenimsiz ve olumsal olanların yan yana geliş dizilerinin gönderimlerinin yerine kendi kurguladıkları üstbelirlenmiş, mutlak ve sabit nitelikte anlam sistemlerini geçirmektir (Ryan ve Kellner, s. 122). 


\section{Turgut Cansever'in Metonimik Düşüncesi}

Turgut Cansever hem mimarlıkta hem toplumsal yaşamda yan yana gelen unsurların dikey bir üstünlük şemasıyla tasarlanmaması gerektiğini düşünür; onun mimari uygulamaları da buna paraleldir. Bu hâliyle, İslami muhafazakârlığın içerik üretiminden radikal biçimde farklı bir kültürel temsil stratejisine yönelmiş; imgelerin, nesnelerin ve aslında mimarlık pratiğindeki tektoniklerin bir araya gelip ilahi kudrete referans vermekten özge ideal anlamlar üstlenmemesi gerektiğine, yani metafor kullanımına karşı durmuştur. Cansever'i düşünceleriyle etkileyen Titus Burckhardt'ın (1994) metaforu mahkûm edip metonimiye önem veren yaklaşımı da bu yöndedir; ona göre İslam düşüncesi, "analoji (teşbih) karşısında 'karşılaştırılamazlık"a (tenzih) öncelik verir"; çünkü, "bir imgenin ne yaşamı, bilgisi ve gücü vardır, ne de diğer nitelikleri taşır; temsil insanı bedensel sınırlarına hapseder" (s. 242).

Bu istikamette Uğur Tanyeli'nin, Cansever'in tasavvufla mimarlık ilişkisini, [Nâdir] Ardalan ve [Lâle] Bahtiyar'ın yaptı̆ğ gibi, yalın bir simgeler sözlüğüne indirgemediğini söylerken tespiti yerindedir: Yapılarında "sayıları, renkleri, geometrik biçimleri belirli tasavvuf kavramlarına işaret eden göstergeler gibi düşünmemiştir. Sembolizmin Orta Çağ’a özgü böylesi ilkel kolaylıklarına yönelmeyişi onun mimarlığını basit bir yan anlamlar alıştırması veya puzzle'1 olmaktan korur" (alıntılayan Düzenli, 2009, s. 180). Dolayısıyla yazılarının satır aralarında bölgesel ve merkezî mimari standartları önerirken, parça bütün ilişkisine dikkat çekerken ya da mekanizmacılık, tezyinilik gibi İslam düşüncesinin tevhit ilkesi etrafında anlamlı fikirlerini öne sürerken metonimik bir yönelime sahip olduğu iddia edilmelidir.

Hatırlatmak gerekirse, metonimide imajlar ya kendileri de parça iken diğer parçalara bağlanır ya parçasını oluşturduğu bütünle ilişkilenir. Ayrıca metonimik temsil, bütünü oluşturan parçaları bir araya getirirken bir parçayı diğerine üstün tutmaz; parçalar arasında eşitlik ilkesi söz konusudur. Dolayısıyla parçalar, üzerlerine ayrıca bir anlam yükü bindirilmediğinden özerk yapılardır. Bu durum, parçaların farklılıklarını olumlayarak özerk birer yapı oluşturduklarını savunan Le Corbusier'nin geleneksel şehirlerdeki organik bütünlük düşüncesine karşı mekanizmacı tasarım anlayışına da denk düşer. Fakat Cansever'e kalırsa bu anlayışıyla Le Corbusier, örneğin ev ile sokağın birbirinden bağımsızlaşmasını savunduğunda bu fikri zaten Doğu'nun şehirlerinden edinmiştir. Bu nedenle Cansever, yapıların özerkliğini savunurken ona göre fikrin asıl kaynağına, Osmanlı şehirlerine yönelir. Daha açılayıcı olmak gerekirse Cansever, inşa edilecek yapı içerisindeki elemanların ya da 
şehirlerdeki tek tek yapıların özerkliklerini, sınırlarını korudukları hâlde mekanik bir bütünlüğün organizasyonuna katılmaları gerektiğini belirterek yapılara "bağımsız tektonikler" (2016, s. 38) bu organizasyona "yığın kolektivitesi" (1992, s. 57) adını vermiştir. Neticede, bu vurgularıyla parçaların her birini idealize edilmiş bir başka anlamı taşımaya zorlanmaktansa onların özerk varlıklarıyla bütünü meydana getirmeleri gerektiğini belirtmiştir. Cansever için, sanat tarihi içerisindeki, fertlerin "özel yerlerini bütünlükle ilişkili olarak" muhafaza ettikleri ve ancak tam bu nedenle, unsurları, parçaları yahut ölçekleri değiştiğinde tahrip olan organistik düzenlemeden farklıdır (2005, s. 28). Ona göre esas bütünlük, "kendi ferdi mekânını yaratan parçaların kompozisyonu ile başarılır" (s. 29).

Cansever' in "fert" sözcüğüne, bunu dilbilimin "gösterge" kavramı gibi de okuyabiliriz, bir mimari enstrümanmış gibi sık vurgu yapması boşuna değildir. Bu durum, toplum içerisindeki bireylerin söz hakkını önemseyerek katılımcllğın altını çizdiği demokratik arayışına da naklen karşılık gelir. Bu görüşte parça ve bütün ilişkisi bu kez, birey ve toplum ilişkisi olarak görünmekte, bireylerin özerkliğine dikkat çekilmektedir. Cansever, bireylerin kattlım haklarıyla birlikte yaşam birimleri olan aileden, mahalleye ve şehirlere doğru organizasyon kalıpları içerisinde özerk hâlde var olmaları gerektiğini savunur. Başka deyişle mimaride özerk parçaların yan yana gelişi nasıl metonimik bir dizge oluşturuyorsa aynı durum bireylerden başlayarak ailelerin, dolayısıyla toplumsal yapıların yan yana gelmesinde de geçerli hâle getirilmiştir. Burası, sözcüklerden cümleler ve cümlelerden metinler inşa etmek gibidir. Nitekim Cansever için mimari yapılar ile toplumsal yapıların birbirine karşılık gelmesi, ev ile aile arasında kurulan bir özdeşlikte belirgin olmuştur. Cansever (2009), "[b]u yoğun ilişkiler sistemi içinde şehrin ilk yapı taşı olan ev, insanın barınma zaruretinin bir ürünü, aynı zamanda ailenin yaşama çevresi ve insandan insana ilişkilerin ve aileler (toplumun organize olmuş birimleri) arasındaki ilişkilerin oluşması yolundaki gelişmenin de ilk aşamasıdır" (s. 101) diye görüşünü belirtmiştir.

Bu düşüncedeki özerk yapılardan mimarlıkta ev ve toplumsal planda aile kurumu bütünleşirken komşuluk zincirleriyse metoniminin yan yana getirici özelliği olarak ortaya çıkar. Öyleyse Cansever'in ileri sürdüğü İslami düşünce tarzında gerek mimarlık ve şehircilik gerekse toplumsal ilişkiler metonimik zincirler içerisinde örgütlenecek dizgelerden oluşacak ve tüm ülkenin kentsel, toplumsal, karmaşık sorunlarının çözümüne dönük çok yönlü bir planlama çabasına dönüşecektir. Bu nedenle Cansever için (1996) “ferdiyetin 
yüceliği" (126), bireylerin veya başka toplumsal yapıların homojenleştirilmeden, "ne iseler o" (s. 129) olarak değerlendirilmesini gerektirerek İslam düşüncesine hayli anlamlı bir düzeyde katılımclık perspektifini getirmiştir.

Cansever'e (1996) göre, Rönesans mimarisinde, duvar inşasında kullanılan taş, bir mecburiyet olmamasına rağmen, sert olma niteliğini bilhassa vurgulamak için gereğinden fazla işlenmiş̧ir; taş kullanımı, kalıcılık, sağlamlık idealine karşılık gelecek şekilde metaforiktir. Cansever, Gotik mimarideki taşın doğal ve maddi karakterini sergilemenin kaçınılması gereken bir eğilim olduğunu düşünmüsstür. Böylece Gotik mimari saklama, Rönesans ise görünür kılma kastıyla metaforik anlatıma yönelmiş, iki hâlde de "ölçülü olmak" yerine "aşırıllılara" gidilmiştir. Bu nedenle Cansever'e göre "Katolik kilisesinin tutumunu temsil eden, maddî varlığı günah olarak kabul eden tasarımcının, mimarın isteğine göre, taş kullanımı ışı ve gölgeyle tesis edilen profillerle değiştirilmiştir" (s. 129). Ancak Cansever'e kalırsa İslam mimarisi, Gotik mimarinin geriye iten ve Rönesans'in öne çıkaran bu anlayışından farklı olarak "malzemeyi olduğu gibi, neyse o olarak kullanır; niteliklerini inkâr etmeden ve önemlerine aşırı bir vurgu yapmadan" değerlendirir. Bu bağlamda Cansever, mimari malzemenin olduğundan farklı anlamlar yüklenip metaforik olarak ya da simgesel yan anlamları ifade edecek tarzda kullanımını eleştirmiş, uygunlukla kullanımı yeterli görmüştür.

Umberto Eco'ya (2019) göre mimari nesneler bildirişim açısından bakılırsa "düzanlamlama" ve "yananlamlama" görevlerini yerini getirir. Eco, düzanlam düzlemine yapılan göndermeyi birinci işlev, yananlam düzlemine yapılan göndermeyi ise ikinci işlev olarak ifade eder. Bu iki işlev arasındaki fark, tarih içerisinde şifrelere ve yorum tutanaklarına göre anlaşılır olmaktadır (s. 35). Örneğin mimarlık tarihçileri, Gotik mimarinin şifrelerinin çözümü için sivri kemer ve tonozun yapısal değeri hakkında tartışmalar yürüttügünde üç yaklaşımı öne çıkarmıştır. Birinci görüş, tonozun taşıma işlevini hayati bulmuş, katedrallerin yüksek ve zarif konstrüksiyonun ancak bu taşıma işlevi sayesinde dengede durduğunu ileri sürmüştür. İkinci görüş, her ne kadar bu izlenim verilmiş olunsa da tonozun statik açıdan bir değeri olmadığını, esas olarak katedrallerin duvarlar vasıtasıyla taşındığını tespit etmiştir. Bir başka görüşse Gotik tonozun statik değerinin sadece inşa aşamasında söz konusu olduğunu, onun geçici bir iskelet görevini üstlendiğini ama inşa sonrasında yapının diğer ögelerinin bu işlevi yerine getirmiş olduğunu düşünmüştür (s. 35). Eco'ya göre tonozun statik değeri, düzanlamlamanın gönderme yaptığı 
birinci işlevidir. Ona göre üç yaklaşım da birinci işlev üzerinden tartışma yürütmüştür; ancak tonozun statik değeri olsun ya da olmasın, bildirişimsel bir değer taşıdığı konusunda şüpheye düşülmemiştir.

Bu noktada tonozun asıl bildirişimsel değeri, yananlam düzlemine gönderme yapan ikinci işlevidir. Eco'ya göre (2019) eğer, "tonoz bir işlevi mümkün kılmak için değil de bu işlevi iletmek, bildirmek için kurulmuşsa, bildirişimsel değeri bir o kadar daha kesin, amaçlı ve geçerli olur" (s. 35-36). Neticede açık olan, "katedral" bildirisindeki göstergelerin, örneğin tonozun ya da vitraylarla bezenmiş duvarların iletiler göndermesidir. Öyleyse katedraller, zaman içerisinde değişiklikler gösterecek şekilde simgesel değer taşıyan unsurlarla şifrelenmiştir. Bu çerçevede Eco, mimari ürünler için toplumsal ve ideolojik açıdan ikinci işlevlerin iletilmesinin birinci işlevlerden daha fazla değer taşıdığını belirtir. Bu düşünce izlendiğinde, Eco'nun vurguladığı “bir araya gelme" niteliğine sahip birinci işlevi, modern döneme uyarladığımızda metonimi, "kutsallığın temsili" olma niteliğini taşıyan ikinci işlevi ise metafor kavramıyla karşılamak mümkündür. Mimari nesneler yan yana gelişleriyle metonimik olarak biçimsel, strüktürel işlevini yerine getirip bağlamlarını kazanırken onların toplumsal bakımdan bildirişimde bulunmalarıysa simgesel yananlamlar kazanmalarıyla birlikte metaforik olarak değer taşımalarını gerekli kılar.

Cansever ise, İslam mimarisinde, onun açısından varlığın salt material boyutundan söz edilirse, Eco'nun altını çizdiği düzanlamlamanın, yani birinci işlevlerin başat olduğunu, yananlamlamanın, başka deyişle ikinci işlevlerinse pek gerekli bulunmadığını belirtiyor gibi görünür. Buna göre yapı malzemeleri, mimari bir ögenin düzanlamlamasının içerisinde edindikleri bağlam ilahi kudretin bir yansımasıdır. Bu geleneği takip edecek mimarın da bunun ötesinde malzemeye yeni yananlamlar kazandırmasının gerekliliği söz konusu değildir. Bu nedenle Cansever, savunucusu olduğu İslam düşüncesinin mimari temsilinde, her bir parçaya, metaforik olarak ideal anlamları açı bir şekilde imleyen ya da örtük biçimde anıştıran anlatımlardan arındırılmış bir mimari yaklaşımı benimsemiştir. Mimarinin birinci ve ikinci işlevinin Orta Çağ’a özgü olmakla kalmadığı, bildirişim açısından özellikle metropollere bakıldığında, birinci işlevlerin yapı teknolojisiyle gelişerek kolaylaşmasıyla ikinci işlevlerin, yani simgesel yananlamlama değerlerinin öne çıtığı ve hatta kültür endüstrisinin de bunu körüklediği bir zamanda Cansever'in bu yalınlığı savunması, onun metonimik bir eğilimle getirdiği mimarlık ve şehircilik anlayışını değerli kılan argümanlardandır. 
Cansever'e (1996) göre İslam mimarisinin yapım sistemlerinde izlediği tutum da bu yönde gözlemlenebilir. Ona göre İslam mimarisi, "Gotik mimarînin hâkim karakterinde yahut 19. yüzyıl ile 20. yüzyılın yapılarında görülebileceği gibi bir yapının büyük bir span [açıklık] ya da olağandışı bir aydınlığa kavuşturulması gibi bir şeyi amaç edinmez. Aksine, İslâm'da teknoloji, sadece kendi önem hiyerarşilerine göre gerçek ihtiyaçları karşılamak amacıyla kullanılabilir. Teknolojiler kendi varlık düzeylerinin kanunlarıyla uyum içinde kullanılırken daha üst düzeylerin kanunlar hiyerarşisine uygun olarak seçilir veya yönlendirilir" (s. 129). Cansever'in bu sözlerindeki "İslam mimarisi"nin bize göre özsel niteliklerini ayırt ederken altını çizdikleri, sözünü ettiğimiz meselelerin bir özeti niteliğindedir: Cansever için bir nesne, örneğin bir taş, bir dizgenin parçası olarak ne ayrıca vurgulanacak ne de gizlenecek bir malzemedir. Cansever, varlıkların kendi var oluşlarıyla ve başka varlıklarla uyumlu olarak yan yana gelişiyle, başka deyişle metonimik ilişkileri içerisinde, her "neyse o" olmasını yeterince estetik bir konumlanış olarak değerlendirdiğinden varlıkların ayrıca anlam yükleriyle donatılıp metaforlar adına nesne olarak kullanılmalarını İslam mimarisine uygun bulmamıştır.

Jakobson için metonimi, daha önce değindiğimiz üzere, parçanın bütünün yerine geçmesi anlamındaki kapsamlayımı [synechdoch] da ayrıca içine alır. Kapsamlayım, bir parçayı ya da bir bütünü onun bir niteliğiyle veya bir kısmını dile getirerek temsil etmektir; dolayısıyla özel türde bir metonimidir. Hatta Cansever, canlı veya cansız, yeryüzündeki nesnelerin bir bütüne mekanik bir biçimde, özerkliğini saklı tutarak bağlandığını çünkü her bir parçanın, esas olan bütünlüğün, yani ilahi kudretin bir parçası ama aynı zamanda tecellisi olduğunu ileri sürüyorsa bu tevhit ilkesi gereği kapsamlayım anlamındaki metonimik düşünce tarzına da sahip olacaktır.

Bu çerçevede Cansever, düşünsel bakımdan yakın göründüğü Geleneksel Ekol temsilcisi Seyyid Hüseyin Nasr'ın (1992) şu ifadesindeki gibi düşünür: “Mimarın kullandığı malzemenin tabi olduğu fiziki güç ve kurallara bile, Allah'ın onlara verdiği nitelikleri açığa vurmalarına imkân tanıyacak şekilde, onların bu niteliklerine saygı göstererek davranmall; böylece onların da yaratılışı simgeleyen uyum ve güzellikten kendilerine düşen payı almaları sağlanmalıdır" (s. 83-84). Öyleyse, İslam medeniyetinde "imaj ve sembollerin genetik temelini" soruşturan Cansever (1996, s. 141), bir varlığın yahut malzemenin kullanımındaki kaygının mesajları taşımak olmasına veya bütün içerisindeki bir parçanın değişken bir şekilde özerk dile getirilişinden çok, sabit başka bir anlamın yerini tutmasına (substitution) itiraz etmektedir. Zira onun merakı, göstergesel bir birimin başka birimler için bağlam vazifesini 
üstlenmesi yahut kendi bağlamını bir sistem içerisindeki birimde edinmesidir; dolayısıyla bu ilgi iç yapıya (contexture) ilişkindir. Ancak Cansever, (1992) yaşanan modern dünyanın "yanında duran ile ahenkli bir beraberlik oluşturmak yerine ona baskın çıkmaya, egemen olmaya" çalıştı̆̆ını kabul eder (s. 229). Bu düşüncedeki "yanında duranla" oluşturulacak ahenkli beraberlik düşüncesi işte metonimik bir temsil düşüncesinin ürünüyken baskın çımak ve egemen olmak, sözünü ettiğimiz gibi tıpkı metaforun hiyerarşik kullanıminı vurgular gibidir.

Cansever' in bu yaklaşımı dünyayı güzelleştirme ülküsündendir. Cansever (2010) bunu İslam sanatındaki tezyinilik bağlamında, "tıpkı bir kolyede kıymetli parçaların yan yana gelmesi gibi" (s. 102) diyerek açıklamıştır. Bütün bunlarla ilişkili olarak, Cansever' in önerdiği şehircilik modelini metonimik bir tarzla ortaya koymasının bir başka sonucu, şehirleşme pratiğine, Ryan ve Kellner'ın (2010) metonimi için söylediği gibi, "gelecek yönelimli, dinamik ve belirlenimsiz" (s. 41) bir anlayış katmasıdır. Cansever' in (2007) Osmanlı şehirlerinin klasik dönemine işaret ettiği "asli düşünce" ilişkisel ve süreç temellidir: Bu nedenle merkeziyetçi, modern kentsel planlama anlayışına, "bir seferde tasarlanıp dondurulmuş ve süresi belirsiz bir gelecek için etkili olabilecek bir hükmün kalıcllğını sağlayacak herhangi bir şey, o geleceğe ihanet etmektir" (s. 346) sözleriyle karşı çıkmıştır.

Bu fikir, yer yer Le Corbusier'i karşısına aldığında da kendini gösterir: Cansever (1992), standartların mühendislik faaliyetleri olarak ele alınmastnın, "gelecek neslin insanı için" (s. 86) bir sınırlama olduğunu düşünür. Bu nedenle Cansever, ucu açık bir kompozisyondan yanadır. Ona göre "buyurgan mimari kararlar" karşısında, parçaları gelecekte yeniden yapılandırmaya, onlara başka formlar kazanmaya uygun olarak tasarlamak gerekir (2007, s. 348). Çünkü, bu yaklaşıma göre "tektoniklerin kitle kolektivitesini oluşturduğu bütünlükler, alt parçalara ayrılabilme, üzerlerine yeni ekler alarak da özelliklerini sürdürme imkânına sahip" (2010, s. 75) olacaktır. Başka deyişle, yapıları "mekanik" tarzda tasarlamak ve alınacak kararlarda mekânları bu anlayışla planlamak, "gelecek meselesine bağlı olarak ileride üzerine alacağı eklentilerin de kaderini belirlemek gibi önemli bir sorumluluğu" yerine getirmiş olacaktır (2010, s. 76).

Turgut Cansever' in görüşlerinden kısmi hâlde esinlendiği Burckhardt' in (1994) "[p]lastik bir sanatta gelenek yaratıcı özgürlükle (ki onsuz sanat, sanat değildir) nasıl uzlaştırılabilir?" yönlü sorusu, şimdiye dek sözünü ettiğimiz dilbilimsel temelli tartışmalardan bakıldığında ilgi çekici sonuçlar doğurur. Saussure'ün belirttiği gibi dil sistemleri toplumsal uzlaşımlara dayanıyorsa 
ve dilsel ögeleri birleştiren bağlantıların yapısı, bu mutlaka vurgulanmalı, zihinsel etkinliklerin çalışma biçimleriyse, Burckhardt'ın plastik sanatlar için değindiği gelenek, şifrelenmiş dil dizgelerine karşılık gelecektir.

Öte yandan geleneksel sanatlar içinde hareket eden yaratıcı, mevcut şifrelerden dilin kuralları uyarınca yeni bağlantılar kurarak dil sistemine katkı sunan kullaniciya denk düssecektir. Ancak toplumsal bir kurum olan Dilin, bireysel edimlere egemen olması nedeniyle, yapısalcı görüşlerin içerisinden düşünüldüğünde sanatçı, yaratımlarını ancak ve ancak toplumsal kurumlara, verili sistemlere, başka deyişle geleneğe bağımlı şekilde gerçekleştirebilecektir. Dolayısıyla bu çerçevede gelenek, Dil; geleneksel sanatçıysa söz edimlerinin icracısı olarak düşünülebilir. Burckhardt, sorusunu dilbilimden yola çıkarak şöyle cevaplamıştır: "Sanatçı, gelenek sayesinde, koşullara, daha doğrusu çalışmasının amacına göre kullanıp uyarlayacağı bir dizi model ya da tipik biçimlere sahip olur. Adapte ederek yaratır, ama bu yaratış belirli yasalara uyar: Modeller ya da tipik biçimler, grameri ve sentaksı olan bir dilin unsurlarıdır; belirli bir sanatta ustalık kazanan kendini dilin kurallarına uydurarak özgürce ifade edebilir, daha doğrusu, dilin kaynakları sayesinde kendini özgürce ifade edebilir" (s. 200).

Şimdi, Saussure'ün dilbilime katkısı, Dili özerk bir sistem olarak kabul edip bir sistemin içerisinden açılama girişimindedir. Dil sisteminin birimleri olan göstergelerin, yani sözcüklerin adlandırılmasının Dil dışından, bir nedene bağlı olarak belirlenmediğini, anlamın dil sisteminin içinde organize edildiğini, dolayısıyla kuralların nedensiz oldukları hâlde uzlaşıma dayand1ğını söylemesi bunun bir ifadesidir (Tura, 1996, 101). En fazla Saussure, insanların sahip oldukları dil yetisini, kalıtımsal aktarımla açıklama yoluna gitmiştir. Kısacası, özerk olan dil sistemiyse de bireyler değildir. Bireylerin ya da sanatçıların özerk olmadıkları, gelenek içerisinde hareket ettikleri, mevcut yasalara bağlı kalma gereklilikleri konusunda Burckhardt da hemfikirdir. Ancak Burckhardt için geleneksel örüntüdeki uzlaşımın Saussure'den farklı olarak bir nedeni vardır; bu neden İslam düşüncesi içinde, ilahi iradeye atfedilmiştir. Bu konuda, Turgut Cansever'in de dahil olduğu İslam düşüncesi hakkında, tanrının vergisi olanla insani pratiklerin birbirinden ayırt edildiği söylemek dahi fazladır. Yine de yöntem bakımından, sistemlerinin işleyişlerini, bunları var eden koşulları geride tutup sadece sistemlerin çalışma ilkelerinin içinden okuma konusundaki ortaklık gün yüzündedir. Burckhardt'ın Dil ile gelenek ve söz edimleri ile geleneği takip eden sanatçının yerine getireceği kurallar arasında kurduğu ilişki de bunu göstermektedir. 
Bu noktada, Best ve Kellner'ın (2011) ifade ettiği şekilde düşünüldüğünde, yapısalcılığa göre simgeler, bilinçdışı ya da toplumsal ilişkiler, yani tüm sistemler tıpkı dil gibi yapılanmışken ortada beliren anlamın türevsel olduğu görülür. Başka bir deyişle yapısalcı düşüncede eğer sistemler de dil gibi yapılanmışsa bu sistemlerin kullanıcıları olan bireyler Dilin, söz üzerindeki hâkimiyetinde olduğu gibi üreteceği edimlerinde, yaratımlarında sistemlerin işleyişine bağımlı kılınmıştır. Dolayısıyla bu yapısalcı düşüncede anlam, "özerk bir öznenin şeffaf amaçlarının yaratısı" değildir; "bizzat özne, dil içerisindeki bağıntıları yoluyla" oluşturulmuştur. Böylelikle yapısalcılığa göre öznellik, "bir toplumsal ya da dilsel inşa (construct) olarak" görülmüştür. Çünkü sözünü ettiğimiz gibi bu düşüncede, özne tekleri tarafından gerçekleştirilen tikel (particular) edimlerin, yani sözün dil sistemleri tarafından belirlendiği öne sürülmüş̧ür (s. 35).

Burckhardt'tan devam edildiğinde; ona göre sanat tarihçileri, eserlerinin esinlendiği manevi hakikati gözlerden yitirerek sanatçının kişiliğine ve ruh hâllerine odaklanıldığı görülür. Ancak İslam sanatlarında yaratıcılık, Avrupa'dakinin tersine, bir sanatçının bireysel ediminin ürünü değildir. Geleneksel İslam sanatlarının yaratıcıları, Burckhardt'a göre (1994), “İlâhî kanunlara 'boyun eğmesi' sayesinde güzelliği üretenin ya da yaratanın kendisi olmadığının, bir sanat eserinin ancak kâinatta düzene itaat ettiği oranda güzel olduğu ve bu yüzden evrensel güzelliği yansıttığı gerçeğinin her zaman bilicindedir". Yazarın, "boyun eğme" ifadesiyle "İslam" sözcüğünün gerçek kelime anlamına gönderme yaptığı düşünceye göre sanatçı, söz konusu teslimiyetiyle yaratıcılık coşkusundan kaybetmeyecek; aksine, kişiler üstü nitelik kazanacaktır (s. 230-231).

Neticede Titus Burckhardt, geleneksel üretim içerisindeki yaratıcllık bahsine, Saussureyen geleneğe benzer bir noktadan, bu geleneğe referansla açıklama getirir. Cansever ise önerdiği şehircilik modeliyle bu akıl yürütmeye katkıda bulunur. Çünkü geleneksel işleyiş, sadece Burckhardt'ın görüşleri üzerinden kabul edildiğinde, geleneğe uygun yapı üretiminin ve toplumsal yaşamın gözetilmesi durumunda, birbirine bağlı ve son derece kayda değer iki problem baş gösterecektir. Birincisi bu modele, bireylerin ya da yapı üretiminde parçaların durağan işleyişe sahip oldukları yönünde bir eleştiri getirilecektir. İkincisi, bu okuma biçiminde, gelenekte yine bireylerin veya yap1 parçalarının özerk varlıklar olmadıkları, yaratıcılıklarının da Burckhardt'ın savunduğu üzere ancak merkezî yasalara itaat etmeleriyle gerçekleşebileceği kaçınılmaz olarak gündeme gelecektir. 
Cansever, Osmanlı şehirlerini ve toplum yapısını bu eleştirilerden kurtarmak üzere geleneğe dönük yeni okuma ve buradan geleceğe dönük bir şehircilik teklifi geliştirecektir. Bu strateji, Cansever' in birbiriyle ilişkili olarak birincisi mimarlık ve şehirciliğe standartlar getirme (1996, s. 131), ikincisi modern çağın getirisinden farklı olarak, geleneksel bilginin temellük edilmesiyle mümkün olan bir uzmanlaşma fikrine ilişkindir (1996, s. 128). Değindiğimiz üzere, Cansever, Osmanlı'nın yapı üretme pratiğinin Le Corbusier' in tasarımlarında olduğu gibi, hatta onun dahi Doğu kültürlerinden edindiğini öne sürdüğü üzere, "mekanik" bir işleyişe sahip olduğunu iddia etmektedir. Böylelikle Cansever, işleyişi organik olmaktan kurtararak akışlara, harekete, üzerine ek almaya, tamir görmeye ve geleceğe tahakküm kurmayarak gerektiğinde değişebilmeye açık hâle getirmiş olacaktır.

Bu metodun çağdaş şehirlere adaptasyonu içinse Cansever, biri merkezî ve diğeri bölgesel, iki yöntemi dikkate alarak standartlar geliştirmeyi benimsemiştir (2010, s. 174). Merkezî standartlar, Saussure'ün toplumsal bir sözleşme olan Dil kavramı gibidir; İslam mimarisinin her koşulda bağlı bulunduğu üslup özelliklerini ancak sadece teknik olmaktan çok, öze ve içeriğe dair prensiplerini ortaya koyacaktır. Yerel standartlarsa, bölgesel şartlara, iklim özelliklerine, arazi yapısına, kullanıcının ekonomik durumuna göre değişebilme hakkına sahip olacaktır. Ona göre mesela mahallelerin oluşumu, belirli standartlar, değerler ve davranış düzenleri içerisinde gerçekleşir; mahalle, “topoğrafik özelliklere uygun olarak gelişen yollar, yol kenarlarında üzerine yerleştikleri arsanın, komşu yapıların oluşturduğu fizikî, sosyal, kültürel, mimarî, tarihî şartlara uyum içinde bağımsız, yüce fertler olarak evler var olur. Yollar boyunca birbirini takip eden ev dizilerinin tezyini düzeni adeta bir beytin iki mısral gibi birbirini tamamlar" (2010, s. 174). Dolayısıyla Saussure'ün dil sistemine bağlı olduğu hâlde bireysel edimler olan söz kavramında olduğu gibi yerel standartlar merkezî standartlara, başka deyişle uzlaşmaya bağlı kalacaktır. Ancak Cansever için bu model, organik olmaktansa mekanik olduğu için, bütünü yansıtan, ona bağlı parçalar, özerklik kazanacak ve Burckhardt'ın sadece "boyun eğen" yaratıcılarından farklı olarak, yine merkezî standartlara bağlı olmakla birlikte ancak bu kez özerk işleyişlerine sahip olarak kalacaklardır. Böylece mimarlıkta merkezî bürokratik politikalarla hareket edilmeyecek, şehircilikte ve toplumsal yaşamda ise şehirler, öbekler hâlinde kendi ihtiyaçları doğrultusunda yönetilecek, mahalleler iç işleyişleri içerisinde birbirinden farklı yaşam birimlerini oluşturacaktır. 


\section{Sonuç Yerine}

Roman Jakobson'un düşünceleri yeniden izlenirse Cansever' in niçin metaforik olmaktan uzak hâlde, metonimik düşünce tarzına sahip olduğu bir kez daha açığa çıkmaktadır. Anımsanacağı üzere, Cansever, sabit ve genel geçer anlamları empoze etmesi nedeniyle metaforik düşünme tarzını tercih etmemiştir. Cansever' in metonimik düşünce tarzı, onu yeryüzünü güzelleştirme ülküsüne, bütünün parçalarının tevhit inancı etrafında, süreç düşüncesi içerisinde yan yana gelmesiyle ilahi kudreti yansıtması gerektiğine götürmüştür. Bunun sonucunda, Cansever için yeryüzünde kutsal mekânlar söz konusu olmayacaktır. Zira mekânların birbirine eklemlenerek dinamik bir varlık kazanmalarıyla, zaman ve mekânın bütünüyle kutsal olduğu fikri belirginlik kazanmıştır. Bu hâlde Cansever' in, İslam düşüncesini mimarlık alanında temsil edebilmek için üretilecek mekânlarda metaforu bir temsil aracı olarak kullanmaya artık ihtiyacı kalmayacaktır.

Sözünü ettiğimiz üzere Roman Jakobson, Saussure'ün Dil ve söz ayrımı ile çağrışımsal ve dizimsel eksen modellerini bir arada, birbirine karşılık gelecek hâlde düşünür. Jakobson, Saussure'ün ikili karşıtlıklarından çağrışımsal ekseni, kültürel bellek havuzundan bir seçmeye dayandığı için Dil ile, dizimsel ekseni ise aktüel bir etkinlik şeklinde kombine etmeye dayandığ için söz ile ilişkilendirir. Dolayısıyla metaforu Dile, metonimiyi ise söze yakın bulur (Lodge, 2003, 65). Sonuç itibariyle, bu okuma takip edildiğinde Turgut Cansever' in bireysel etkinliklere, birincisi "ferdiyetin yüceliği" ve ayrıca, mimari yapısal parçalara ise "bağımsız tektonikler" düşüncesiyle yaklaşıp özerklik tanıması anlamlı olur. Burada bireylerin toplumsal uzlaşmalara bağlı kalsalar da özgür varlıklar olmaları gibi tektoniklerin de bir "kolektivite"nin parçası olsalar dahi bütünden özerk oldukları kabul edilmiştir.

Bu durumda Cansever, toplumsallıkta fertlerin ya da mimarlık ve şehircilikte yapı birimlerinin merkezî kararların mutlak belirleyiciliği altında kalmalarındansa kişisel ya da bölgesel özelliklere uygun hareket etme haklarını teslim etmiştir. Çünkü ona göre, ister mimari isterse toplumsal olsun, dilbilimsel ifadeyle her bir birim, ilahi olanın yaratımlarının kısmi bir parçasıdır; dolayısıyla her bir parçanın tasarımı, bütünün hayal gücünde canlandırılmasını gerekli kılmak için gerçekleşecektir. Başka deyişle Cansever, yapılı çevrede insanın bir etkinliği olarak inşa edilecek bir araya getirişlerin de ilahi kudretin, onun yaratıcılığın bir aynası olduğunu düşünmekle metonimik bir düşünce tarzına sahip olduğunu pekiştirmektedir. Bu bağlamda, Cansever için dünyayı güzelleştirmek ya da tezyinilik, gerek yapıların yan yana gelerek ancak 
dil birimlerinde olduğu gibi, birbirlerine göre anlam kazanarak bir dizimi oluşturması ve gerekse her bir birimin tevhit inancı gereği, bütünlükleri temsil edecek şekilde özerk bir mevcudiyete sahip olması metonimik bir düşünce tarzının ifadesidir. 


\title{
Extended Abstract
}

\section{Linguistic Considerations on Turgut Cansever's Urbanism}

\author{
$*$ \\ Fatma Sinem Akbulut \\ ORCID: 0000-0002-6621-0436
}

This study applies several linguistics concepts to examine the way Turgut Cansever's thoughts are reflected in Islamic architectural designs and construction. In examining this, first, Saussure's distinction between language as a social construction (langue) and language as individual speech (parole) and his distinction between syntagms (syntagma) and paradigms (paradigma) are discussed. Next, Roman Jakobson's notions of metaphor and metonymy are addressed in contrast to Saussure's dualities. Jakobson, in adhering to the Saussurean tradition, approaches the distinction between language and speech and the syntagmatic and paradigmatic axis models in terms of reciprocity, associating the syntagmatic axis with language, as it is based on a selection from the cultural memory pool, and the paradigmatic axis with speech, as it is based on an actual activity. In other words, he finds metaphor to correspond to language and metonymy to speech (Lodge, 2003, 65). These concepts are analyzed according to the views expressed by Ryan and Kellner.

Cansever opposed the idea of hierarchy in terms of both urban design and social functioning, and his architectural designs reflect this objection. Instead, in his designs he applied a cultural representation strategy that was radically different from the hierarchical architectural understanding and social ideology. Through this strategy he maintained his conservative Islamic identity, arguing that the images, objects and tectonics in architectural practice should reference God, which meant that he refrained from using the symbols associated with the hierarchical ideology in establishing the relationship between Islam and architecture. Here, the concept of metaphor, as developed by Ryan and Keller, can be used to contrast Cansever's anti-metaphor approach to design; the metonymic intellectual orientation proposed by Ryan and Keller can 
be seen in Cansever's designs in terms of the central architectural standards he applied, the attention he drew to the part-whole relationship, and his ideas of mechanicism and ornamentalism, which are only meaningful when we consider them in light of the Islamic principle of Tawhid (unification).

According to the concept of metonymy, images, as individual parts themselves, are either connected to other parts or related to the whole to which they form a part. Contrary to metaphor, metonymic representation advances the principle of equality insofar as it brings together the parts that make up the whole; that is, one part does not take precedence over another. Therefore, while the parts are autonomous structures, they cannot be understood outside of their relationship to the whole. This dynamic appears to be identical with the mechanistic design conception developed by Le Corbusier, who opposed the traditional idea of organic whole seen in some cities by affirming the differences of architectural pieces and forming autonomous structures. According to Cansever, Le Corbusier's idea, for example, that the house and the street should be independent entities, is based on the cities of Eastern civilizations. Cansever, however, focuses on autonomous structures in the Ottoman cities, which for him are the real source of this idea. He referred to the structures as "independent tectonics" and this organization as "mass collectivity", stating that the elements within the structure to be built or the individual structures in the cities, should participate in the organization of the mechanical whole in order to preserve their autonomy and boundaries. Later, Cansever would insist that each of the parts should form the whole with their autonomous existence rather than being forced to carry an idealized meaning.

According to Cansever, this relationship between the part and the whole corresponds to a democratic conception, where the part and whole represent the relationship between the individual and society, with attention being drawn to the autonomy of individuals. Cansever argued that individuals should exist autonomously within the organizational patterns of the family, which are living units, the neighborhood, and the cities, along with the preservation of their equal participatory rights. In architecture, just as the combination of autonomous parts constitutes a metonymic system, the same is valid for family dynamics, and therefore for social structures, starting from individuals. Among the autonomous structures in this system of thought, the house in architecture and the family institution on the social plane are integrated, with the neighborhood functioning as the metonymy of these two en- 
tities. In Cansever's approach, the social relations operating within architecture and urbanism consists of systems that must be organized in metonymic chains and transformed into a multi-faceted project to resolve the country's urban and social problems. From this view, Cansever (1996), argued that "the supremacy of individuality" (126) lent a meaningful perspective on the idea of participation to Islamic thought by requiring individuals or social structures to be evaluated in terms of "what they are" (p. 129), without homogenization.

Turgut Cansever also sought to develop architectural standards at the central and regional levels (2010, p. 174). Accordingly, central standards correspond to Saussure's concept of language, which he proposed was a social contract, and points to Cansever's idea that Islamic architecture has stylistic features to which it is bound under all conditions. These features, it is important to note, reveal the principles of essence (form) and content rather than being technical. Regional standards, on the other hand, can change according to local conditions, climatic characteristics, land structure, and the economic status of the users. Accordingly, neighborhoods should be shaped on the basis of certain standards, values and behavioral patterns. Although connected to Saussure's language system, local standards adhere to central standards, or in other words social consensus, as in the concept of speech, which is an individual activity. It is important here to remember, for Cansever, this model is not organic, but mechanical; therefore, although it reflects the whole, the parts connected to it are autonomous. According to this approach, the architectural decisions to be taken will not be driven by bureaucratic policies; rather, cities will be managed in line with their subjective needs and differences, and neighborhoods will form autonomous living units with their decentralized functioning. In this approach, Cansever's reference is Ottoman cities. Using the planning model of the Ottoman cities, he was able to adapt his ideas to Turkey's modern cities, where he sought to reflect the relationship between the traditional social life and Ottoman art.

To conclude, the metonymic thought of Turgut Cansever led him to pursue the ideal of beautifying the world: He argued that by integrating the parts of the whole, as a reflection of the tawhid (unification) belief of Islam and philosophical principles, the design should reflect the divine power. For Cansever, there is no question of sacred spaces, as all of time and space are completely sacred, a belief that is apparent in his articulation of spaces and their dynamic existence. Therefore, he felt that metaphor was not needed as a means to represent Islamic thought in the new architectural spaces produced. 
However, we argue that this idea is not limited to urbanism for Cansever, rather, each structure, whether it is architectural or social, is linguistically speaking, a partial unit, a "part" of the creation of the divine; therefore, the purpose in the design of each part is to facilitate imagination of the "whole".

\section{Kaynakça/References}

- -. (1996). İslâm mimarîsi üzerine düşünceler. Divan: Disiplinlerarası Çalı̧malar Dergisi, (1), 119-146.

- -. (2005). Mimar Sinan. İstanbul: Albaraka Türk Yayınları.

- -. (2009). İslam'da şehir ve mimari. İstanbul: Timaş Yayınları.

--. (2010). Osmanlı şehri: Şiir'den şehir'e. İstanbul: Timaş Yayınları.

Armağan, M. (haz.). (2016). Kubbeyi yere koymamak. İstanbul: Timaş Yayınları.

Barthes, R. (1993). Göstergebilim ve şehircilik. Göstergebilimsel serüven.içinde (Çev. M. Rifat, S. Rifat). İstanbul: Yapı Kredi Yayınları.

Best, S. ve Douglas K. (2011). Postmodern teori: Eleştirel soruşturmalar. (Çev. M. Küçük). İstanbul: Ayrintı Yayınları.

Burckhardt, T. (1994). Akln aynasl: Geleneksel bilim ve kutsal sanat üzerine denemeler. (Çev. V. Ersoy). İstanbul: İnsan Yayınları.

Cansever, T. (1992). Şehir ve mimari üzerine düşünceler. İstanbul: Ağaç Yayıncllı.

Düzenli, H. I. (2009). Vefeyat: Turgut Cansever (1920-2009). İslam Araştırmaları Dergisi, $22,160-181$.

Eco, U. (2019). Mimarlk göstergebilimi. (Çev. F. E. Akerson). İstanbul: Daimon Yayınları.

Jakobson, R. (2003). Metaforik ve metonimik kutuplar. (Çev. E. E. Çakmak). kitap-lık Dergisi, 65 (Ekim), 76-87.

Lodge, D. (2003). Eğretileme ve düzdeğişmece. (Çev. M. H. Doğan). kitap-lık Dergisi, 65 (Ekim), 65-69.

Nasr, S. H. (1992). İslâm sanatı ve maneviyatı. (Çev. A. Demirhan). İstanbul: İnsan Yayınları.

Rifat, M. (1998). XX. yüzyllda dilbilim ve göstergebilim kuramlarl: 1. Tarihçe ve eleştirel düşünceler. İstanbul: Yapı Kredi Yayınları.

Ryan, M. ve Kellner, D. (2010). Politik kamera: Çă̆daş Hollywood sinemasının ideolojisi ve politikası. (Çev. E. Özsayar). İstanbul: Ayrıntı Yayınları.

Saussure, F. (1998). Genel dilbilim dersleri. (Çev. B. Vardar). İstanbul: Multilingual.

Tanyeli, U. ve Yücel, A. (haz.) (2007). Turgut Cansever: Düşünce adamı ve mimar. İstanbul: Osmanlı Bankası Arşiv ve Araştırma Merkezi ve Garanti Galeri Ortak Yayını.

Tura, S. M. (1996). Freud'un Lacan'a psikanaliz. İstanbul: Ayrıntı Yayınları. 